\title{
Multiculturalism Reconsidered. Bilingual Education in Guatemala
}

KEY WORDS

Guatemala, multiculturalism, Mayas, culture, Mexico, indigenism

\begin{abstract}
Drozdowicz Jarema, Multiculturalism Reconsidered. Bilingual Education in Guatemala [Wielokulturowość wymyślona na nowo. Edukacja dwujęzyczna w Gwatemali]. Kultura - Społeczeństwo - Edukacja nr 1(7), 2015, Poznań 2015, pp. 21-34, Adam Mickiewicz University Press. ISBN 978-83-232-2944-5. ISSN 2300-0422

The modern Maya movement is an example of a new sort of indigenous cultural activism. The long lasting struggle for indigenous rights had finally led to the renegotiation of the social, legal and political order in countries like Guatemala and Mexico. Today we witness a vibrant indigenous activism in many fields, like education for example. This paper deals with the issue of multicultural education in the mentioned countries, but also it presents critical problems of a wider process - i.e. regaining cultural freedom after 500 years of marginalization.
\end{abstract}

\section{Clash of civilizations}

We may fairly say that over five hundred years after the arrival of Europeans in the New World most of the Latin American societies did change significantly in terms of their social structure and national culture. Just recently, we had witnessed a widespread emergence of various emancipatory movements across Americas which happened in the last two decades; each of them attracting indigenous population into the mainstream on a different scale. This process has clearly drawn the attention onto the field of politics and culture in countries like Bolivia or Mexico, who face a similar problem. This problem is made by the coexistence of two cultural streams, who not necessarily share the same interests, values and culture, In consequence of the existing gap between those two, the attempts of reconciliation and dialogue are still considered by many as amenable 
to failure. The first of the mentioned streams connects the white and mestizo culture in a broad sense of a Western and European tradition ${ }^{1}$. It is based on an assumption that there might be just one direction of social modernization - i.e. accepting the dominant role of the Western civilization. The other one joins however diverse native groups, who often differ in terms of culture from each other significantly and until now they were unable to build a consistent front of indigenous organizations. The reality of last years has shown that this doesn't have to be the case and more and more native Americans persuade a vision of a pan-American movement for indigenous rights. Culture and politics became thus in last decades an issue of high importance in the whole Latin American region after long years of conflict. To understand the nature of the conflict we have to acknowledge the fact that the confrontation of the two worlds was since the first contact of Europeans with the native population marked by violence, injustice and suffering and still is imprinted in this manner in the collective social memory. The Indio was for a long period of time a figure of instrumentalized politics against anyone, who does not accept the dominance of white culture and identifies himself with the indigenous tradition. Cultural assimilation and acculturation were taken for granted as a tool of modernization. The clash between western future and indigenous past has divided the Latin American societies into a dichotomy of modern white society and marginalized rural Indios, which cultural and political activism was for a long period of time considered as insignificant in terms of national culture.

\section{The aftermath}

Today the cultural and political sphere is however still troublesome in the Latin American context, as it tackles the issue of historical relations of Native Americans and the descendants of European conquerors. The historical aspect of those relations affects contemporary discourse on Latin American societies in its wide range. This specific merging of past and present might be regarded as well as a constant element of the Latin American reality. Especially, when it comes to the indigenous aspect of the phenomenon the mentioned duality seems to direct the societies of the region into a complex discussion on their future. As the celebrated Mexican author and Cervantez Prize winner, Carlos Fuentes states in

${ }^{1}$ In relation to the context of Central and South America the use of the term mestizo is the most accurate. It describes a general process of race mixing (mestizaje), as well in cultural terms (mestizaje cultural). It is also very risky to use the term Creole in this context as in most Latin American countries (except the Caribbean region) it is associated clearly with the descendants of Spanish colonizers. 
relation to the situation in his home country: "The Indian world of Mexico offers an opposition between the visible and the invisible. (...) The European conquest of Mexico left the Indians a defeated people, and sometimes a defeated people prefer to go unnoticed. They become at one with darkness, wishing to be forgotten so as not to be struck once more. (...) The Indians became a part of the Terra Incognita" (Fuentes, 1997: 27-28).

A significant change begun along with the processes of national reconciliation, peace talks between Latin American governments and left- and rightwing paramilitary organizations. Slowly the societies of the region started to accept the ongoing change as necessary aspect of modernization in a global context. The division between the white and mestizo elites and indigenous groups also started to crumble. More and more native organizations, intellectuals and activists joined the efforts to overcome the existing obstacles and participated in social, political and economic reforms in states like Mexico, Colombia or Brazil. The movement towards a better, more democratic future has been made thanks to many initiatives undertaken not just by mainstream personas, but also by indigenous organizations and people with no earlier political experience whatsoever ${ }^{2}$. Although the declarative side of this process became visible in the social debates, the social praxis has shown that the existing gap between those two fractions is much deeper and harder to deal with than one could thought. Historical animosities and existing stereotypes regarding both groups had once again shown their vitality. Cultural aspects of the planned social, political and economic reforms became an important point in plans for a future prosperity. Countries with a large number of indigenous population, like for example Guatemala, were thus forced to deal with culture in the first place and a new approach towards the understanding of the term "national culture" had to be worked out.

\section{Guatemalan transition}

In the early 1990's the Central American state of Guatemala went through such a radical make-over when it comes to its political, social and cultural issues. This transgression was also similar to many other countries in Central and South America in that time. The ongoing peace process between leftist guerrillas and the government and right wing paramilitary militias, or the process of national

\footnotetext{
${ }^{2}$ Many indigenous forms of political activism had at the beginning a very local character, and they were dealing with issues such as land partition and forms of labour division consistent with indigenous traditions. This is why land reforms are often a starting point and a central issue in all modernization debates in Latin America today.
} 
reconciliation and dialogue were significant for the contemporary shape of the Guatemalan society. However, the specific structure of that society is being still characterized by an existing conflict between two main groups - the descendants of the Spanish conquistadores and mestizos on one side (so called ladinos) and the native Indios on the other that is all the groups identifying themselves with the indigenous population and culture. The gap is being made here (just like in similar cases in Mexico or Bolivia) by a long lasting historical discrepancy between the ladinos being in power and the marginalized Indios. The conquest of the Americas is therefore building a ideological discourse behind the social, cultural, economic and political diversification in today's Guatemala. As for a rural country with almost no natural resources Guatemala is dependant on agriculture. Rural areas are inhabited mostly by indigenous population, who's economic situation is dependant on land owners (latifundistas), mostly Spanish speaking ladinos, who hold $90 \%$ of the agricultural valuable land. Despite the fact that Indios make a large percentage in the Guatemalan population, they were for a long period of time marginalized and pushed outside the political and social mainstream, which ideological foundation was for last few decades based on the rejection of indigenous culture and languages, seen by whites and mestizos as not worth of any interest. This diversification of national culture in Guatemala, was visible not just in this country, but also in whole Latin America. Native Americans were, and still are, perceived by a large part of the white societies as somehow inferior in terms of race and culture to the civilization of whites.

\section{Linguistic landscape of Guatemala}

The contemporary linguistic landscape of Guatemala presents a very diverse picture. This diversification is related to a distinction based more on the difference of local languages belonging to the Mayan language family, than a difference between various language families. This doesn't change the fact that the official language of Guatemala is still just Spanish castellano. This situation is grounded in constitutional act from 1965 called "Ley Orgánica de Educación", a legal act confirming the primary role of Spanish and the linguistic education as a part of the process of social development. Spanish was supposed to be in the eyes of law makers a national language and the indigenous communities were supposed to be incorporated into the state system through advancing linguistic education. However, it doesn't mean that Spanish is broadly used by the Indio population today. Most of the Indio groups in Guatemala do not use this language on every day basis and it is not seldom that some Mayas don't speak Span- 
ish at all. They use just the local Maya language related to the region they live in, a local community, or sometimes even to a particular township. The general number of contemporary Maya languages is being estimated as 51 , including the local dialectal forms. Not so long ago two Mayan languages were functional, which today are being treated as extinct, however the groups that used them remain as culturally separate groups. From this 51 we may distinguish 21 languages which belong to the Mayan linguistic family and this number makes also the basic distinction of the country's ethnic diversification of the Mayan groups. These languages are: Acateko, Avalateco, Chuj, Chorti, Itzaj, Ixil, Kanjolobal, Q’aqchikel, Q'eqchi, Quiche, Mam, Mopan, Popti (Jakalteqo), Poqomchi, Poqomam, Sakapulteqo, Sipaqapense, Teko, Tzutijil, Uspanteko. This diversification appears more clearly when we accept the fact that $70 \%$ of all languages used in Guatemala are being more or less derived from just four of these Mayan languages - Quiche, Mam, Q'aqchikel and Q'eqchi. The last one third is however divided into 16 various idioms.

Except Spanish and diverse Mayan languages we may find today in Guatemala several ethnolects with no relation to Mayan or Indo-European linguistic family. These are the Garifuna language from the arawak family and the isolated and treated as extinct Xinka language. The Garifuna language is being used by around 17 thousand people called the Black Caribs, which make an ethnic group living on the Atlantic coast throughout Central America - starting from Belize and ending in Nicaragua. Its ethnic origins reach back to the end of the 17th century, when the escaped black slaves mixed with native Caribs on the island of St. Vincent. After a military conflict with the British troops they changed their habitat to the coast of Honduras and had spread slowly through in the whole region. The Garifuna came to Guatemala by the end of the 18th century as forced settlers and live today around the cities of Puerto Barrios and Livingston on the north east coast of the country. Contrary to the Garifuna, the Xinka language is not in use today and is considered as isolated, but few researchers link it to the Lenca language. The Xinka ethnic group is still living in eight towns (municipios) in the department of Santa Rosa and uses Spanish (Tzian, 1994: 25).

Mayan languages in Guatemala are being distinguished by a significant disproportion of the number of users. From small groups, counting a dozen of elders (like in the case of Itzaj Maya) up to the large groups counting almost 2 million people (like in the case of Quiche Maya). These discrepancies in the language structure have their consequences in the spatial placement and density of population by the particular Maya groups. For example the Q'eqchi Maya are dispersed on a vast area in the middle of Guatemala, but a comparatively large group of Q'aqchikel Maya inhabits a relatively small piece of land around the 
Atitlan Lake. Therefore a precise description of the linguistic structure of the Maya groups may cause some trouble. This situation has been caused by long lasting migrations of the Maya population inspired by severe political repressions starting from the 1950's where the civil war broke out between the state and the guerillas. Migrations of whole Maya groups into areas far from their original homeland complicate every attempt to reconstruct the map of the genuine placement of all Maya communities. Nonetheless, the most numerous groups of Maya dominate the landscape. The statistic relation of all users of Maya languages, which we are able to identify with the category of Indio to the ladino population is as 1 million 700 thousand to 3 million 800 thousand.

\section{Building networks through institutions}

The proportions of the particular linguistic groups in Guatemala are also based on various statistics made by institutions and organizations who follow different political interests. These organizations don't have to have always a political character. Recent activism of religious denominations converting whole local communities may also affect the reliability of the sources ${ }^{3}$. Such an uncertain source of data is characteristic in the Guatemalan case, not just in relation to languages. The political dimension is also attributed to many institutional and Mayan initiatives in the field of linguistic education. The idea that a common national language is to be introduced is one of the basic tasks the Guatemalan state sets as a priority today. The practical realization of unification of the society on the level of language is however put under a question mark. The attachment of the Maya people to their local languages is, in the eyes of the government, the main obstacle for achieving this goal. Governmental attempts directed towards homogenization of national culture (also through mono-linguistic politics) stand in a clear contradiction to the ideas of the Maya revitalization movements, which started to gain wide interest in the 1990's along the peace process and the peace treaty signed in 1994. Therefore the idea of cultural pluralism stands in opposition to the actions undertaken towards creating a single cultural pattern by the ladino elites. The consequence of this ideological clash is an inflammation of the exist-

\footnotetext{
${ }^{3}$ One of the most known Protestant denominations interested in language politics and gathering data is the US based Summer Institute if Linguistics (SIL). The conversions from Catholicism (or folk version of the religion) to Protestantism were the most common in the last decades. There are also other non-Christian groups today active in Guatemala. There are reported cases of conversions to Islam of local traditional Maya communities. These are however related to the traditional political role of the village chief and his influence on others members of local communities.
} 
ing animosities between the two groups. How the linguistic element of that conflict is being used by both sides becomes more clear when we include the fact, that Mayan languages today are an object of unification, for example through creating an unified alphabet, which is more adequate in the inscription of most of Mayan languages. Such an alphabet was created already in 1991 and gained some popularity even among Maya groups in south Mexico. By that time Mayan languages could be inscribed correctly in Latin alphabet only in a limited manner.

Nevertheless the most effort in the process of the revitalization of Mayan culture in Guatemala. is put in language education. Until the 1980's Spanish was the only language taught in public schools. Bilingual education started by the end of decade and even then it was put into praxis just in several isolated cases. Spanish lessons were for a long time an important part of the ladinization policy, which by Guatemalan state was called castellinization. The breaking point for the language education of the Mayas was 1965. In that year a program called Castellinization Bilingue was launched with the support from United Nations. The program was dedicated to improving the methods of teaching Spanish to Mayan children and simultaneously to the inclusion into national culture by making for the Indios possible to fulfill the educational duty. The employment of bilingual teachers made it possible for Mayan children to get closer to the civic model promoted by the state. Castellinzation Bilingue was functional until 1970's, when the fight with the guerillas had escalated. The intensity of fights with leftist groups in the 1980 's had contributed to the emergence of situation where language policy has been merged with military violence and intense assimilation of the Indios, which had led to a decrease of the number of Mayas learning in public schools. An exception here is made by an initiative called Proyecto Nacional de Educacion Bilingue. The project started in 1981 and ended in 1984. Maya children, who graduated in a basic Spanish course in elementary schools still had limited competences in using that language. The ministry of education had proposed teaching the children Spanish for two years, until they achieve a sufficient level. The program, financed in one third by the American Agency for International Development has been welcomed by many ladinos hoping for a appeasement of the existing conflict which in their opinion had mostly a cultural basis. Even a new name for the first year of classes has been introduced (preprimaria instead of castellization) to diminish the image that the program's only goal was cultural assimilation. The project's demise had not changed much in the educational situation of the Mayas. Maya languages and culture was an object of ongoing assimilation efforts, and everything what had to do with them was to be vanished (for example Maya languages with over a million users were deliberately called "dialects"). This official policy was not much effective because of the fact that 
there were not enough schools and the enforcement of the educational duty had little effect. Of course it also doesn't mean that Spanish was perceived by Mayas in that time just as a language of oppression. It was used widely as a communication tool on the level of ladino/indio relations and slowly also between various ethnic Maya groups. With time bilingual competences became "a pragmatic solution to the enforcement of political and socio-economical powers" (Fischer, McKenna-Brown, 1999: 167).

The knowledge of Spanish declared openly by many Mayas is therefore not a simple rejection of traditional cultural values. Many meetings of Maya organizations and institutions are being held in Spanish, which connects the members of these organizations on a interpersonal level. A good example of that mechanism is delivered by a Mayan Peace Noble Prize winner and a Maya activist, Rigoberta Menchu Tum, who admitted that she had learned Spanish because of the need to communicate with activists from other Maya groups and to attract international attention to her cause. It is also a mistake if we assume that contemporary Mayas omit to learn other languages than their own. Often we may meet people who speak a handful of languages, including Spanish. However we cannot tell the same about the ladinos. Ladino are mostly reluctant when it comes to learn local Maya languages, as Spanish is still seen as the only national language by many people in big cities. As an exception might be regarded the region of Alta Verapaz, where some German migrants had settled and adopted the Q'eqchi language as their own.

\section{Role of education in cultural politics}

It is quite clear that the issue of language education in today's Guatemala is not characterized by stagnation. Ley Organica de Educacion allowed the use if Maya languages in learning Spanish as a basis for further education. Today plans are being made to introduce a new project called Programa Nacional de Educacion Bilingue (PRONEBI), which is supposed to change the language situation of the Mayas. Although the first outline of the project appeared already in 1984 it is the reality of the recent years which has made it into praxis. It is being considered as an important tool in the Maya revitalization movement and in maintaining their cultural identity within the model of a future multicultural state. According to the idea of the project, a common bilingual education in public schools is being planed - in Spanish and local Maya languages. The authors of the initiative call it "parallelism", in the sense that both languages should be developed equally. The idea had also been criticized by some ladinos, insisting that this project is being 
undertaken only by Indios for Indios. It doesn't change the fact that PRONEBI is troubled today by lack of funds and not on a level its authors would like it to see.

The lack of large funding of bilingual education in Guatemala might be strange, if we take into account that the former minister of education Alfredo Tay Coyoy was representing the Mayas as the first Indio official in the government. Nonetheless, the actions undertaken by Coyoy and other politicians had contributed to a new image of the Mayan struggle for self-determination. Education is today one of the most significant fields, where Mayan identity is being reframed. The cultural, social, political and economic transition affects the Maya in Guatemala in the same manner as other indigenous groups in Central and South America. This wide spread phenomenon of revitalization and reconstruction of traditional cultures has an influence on the construction of pan-Indian networks through out Latin America and even United States and Canada. Language education is a significant part of actions of many indigenous activists, and the situation in Guatemala may serve as a role model for societies of similar structure. Guatemalan educational initiatives are based on ideological foundations, which take the cultural basis for granted and try to popularize it among all Maya groups in the name of the pan-Mayan movement. Education is here taken as a sphere of articulation of such postulates for many Mayan activists and the new schooling institutions have a significant political role to fulfill. Recently created schools called escuelas de autogestion are being controlled by local communities, but they are also building a close working network of educational institutions across the country. These Escuelas Mayas take their goal to "incorporate education into the Mayan culture, and not to incorporate Mayan culture into schooling" (Fischer, McKenna-Brown, 1999: 220). The politics of schooling in contemporary Guatemala is a part of a general effort to popularize cooperation among various Maya groups and to legitimize Mayan culture as a integral part of national cultural discourse. The so called "movement of linguistic loyalty" expresses these actions focused on strengthening Maya identity and the process of reconciliation between the Indios and ladinos. This situation is recently taking shape in the educational field, where bilingualism is more and more often seen as a necessary competence in building the future multicultural society.

\section{Multiculturalism in Guatemala}

Guatemalan concept of multiculturalism is certainly a specific version of the idea of cultural and political pluralism, closely linked to the modernization of the country. The political ties between local Maya communities and ethnic groups 
are being perceived today as a beginning of the construction of a network of cooperation not just between the Mayas themselves, but also all indigenous people in Latin America, or even all former Third World countries. This movement is being perceived by many activists as a chance and an opportunity for bringing the postulates of the groups neglected until now by history into the light of world community attention. They are often joining forces with organizations and institutions, who although do not represent indigenous groups directly, but still remain a similar worldview and political goals. An unified front of the Maya and other Indio groups and the alter- or anti-globalism movement became a significant power in shaping the social, economic and political processes in today's Latin America. The "turn left" in the politics of the region in the last years might be regarded here as a clear sign of progressive democratization in countries like Mexico or Guatemala. Certainly democratic representation of ethnic minorities in those countries is still a question of future actions, but contemporary initiatives lead the way to do so.

Nevertheless, they are being put into the complex reality of the region. The postcolonial context of such actions like the language education projects in Guatemala is by the native groups of Mexico, Guatemala, or Bolivia perceived as a historical chance for public expression of Indio identity on a global scale. The engagement of Maya activists, language teachers and intellectualists is a factor of change, contributing to global dynamics of cultural and political transgressions, at least in relation to former postcolonial countries. They desperately need a political legitimization of their identity basis and language. Bilingual education in Guatemala plays an important role in shaping the outcome of this process. This may also explain the level of engagement Mayan intellectuals show in their participation in the public life. Thanks to introduced political changes the question of linguistic diversity and its influence on pan-Mayan and local identity gains in today Guatemala on significance. Linguistic research, ongoing literacy and raising of importance of Mayan idioms had led to the emergence of a needed institutional background, which is supposed to strengthen the level of education among Mayas, knowledge of a specific language and, in consequence, change the status of a particular Maya group. To the most effective institutions, who put these tasks as their goals, we may count the Institute of Linguistics, created at the Rafael Landivar University thanks to the actions of Catholic intellectuals gathered around the Instituto Santiago, and the most important of all institutions Academia de Lenguas Mayas de Guatemala (ALMG). All these institutions employ academic staff well known in world scientific circles and are successful in revitalizing Maya culture. Numerous scientific symposia, linguistic conferences and congresses have mostly also a broader meaning. Thanks to organization of 
such events other Mayan cultural activities are made possible and the they contribute to a wider presentation of current problems of the Maya communities to the ladinos. On the other hand, the Maya themselves do see those linguistic institutions as creating cultural reality and as defendants of the interests of small indigenous communities on a local and national level. Research interest shown by scholars in those institutions transforms in such cases into political activism, which in consequence leads to the fight the rights of these communities, especially when linguists see particular Mayan idioms as endangered. For example part $f$ the researchers is focused on presenting the movements acting against the phenomena of native language loss. They postulate broadening of context of the linguistic research towards the postcolonial societies in general, as well to integrate in their research the influence of globalization processes and incorporation of modern Western patterns into traditional Mayan culture. These phenomena calls for preventive actions as they tend to get more intense in the future.

Some critics of these initiatives, like the Summer Institute of Linguistics, highlight the leading role of urbanized Mayas in contemporary activism of this group. The main argument of SIL against them is based on the assumption that a narrow Mayan elite cannot represent true interests of the rural majority. Furthermore, Mayan activists are being accused of instrumentalizing their cultural traditions to gain casual political support within and outside the country and of reversing old structures and putting this time the Mayas on top of an unjust system. This kind of critique is diminished by the Mayan language loyalty movement, as it puts the rejection of political agenda as its motivation for action. It puts also a specific model of multicultural dialogue and co-existence of various ethnic components as the basis for the new Guatemalan democracy. As an example of such peaceful transition from a militarized regime to democracy is being drawn from the experience of the Yiddish revitalization movement in Eastern Europe and the Rhaetian language movement in Switzerland. Such a declaration might become more clear, when we recall the phenomenon of institutionalized violence in Guatemala, which lasted from the 1950's until 1994. The so called La Violencia is a collective experience of violent clashes between the leftist guerilla and the government, which took place in the context of Cold War era and the confrontation between the United States and their allies and the Soviet Union with their satellite states in Eastern Europe, Cuba, and other parts of the world. In most cases the victims of those military actions were the Maya communities, stuck between opposing forces. Memory of the violent past puts therefore a question mark under all initiatives which deal with rhetoric of confrontation. In consequence rejection of violence of any kind is a characteristic part of modern Mayan political activism, which tends to stress out the need for more cultural, than 
political solutions of the status quo. The revitalization of the Mayan culture is treated as a source of the new national identity, including traditional preColombian customs and the heritage of Spanish colonizers and their descendants.

\section{Mayan revitalization movement today}

Mayan revitalization movement is being animated nowadays by urban and well educated Mayas. It emphasizes the relation between ethnic identity and language. The modern network of cooperation between various local activists and the leaders of the pan-Mayan movement creates the field for further actions taken on a global scale. It is possible also due to large Mayan diasporas outside Guatemala, for example in the United States. Mayan migrants across the world reveal a common identity, although they still feel attached to their own particular language group in the first place. Their identity structures do not exclude however other self-identification levels. On the one hand Mayan migrants show their attachment to other Latin American minorities in countries like United States. Although a large number of them has only little knowledge of Spanish they often see the link between other Latinos, like the Mexicans or migrants from El Salvador. On the other hand, as Mayas they express a feeling of belonging to a larger group of all Maya speaking groups, or even all "indigenous" people. Public expressions of sympathy with Indios from the Amazon, or Mexico are not seldom. Their vision of the world takes into account a specific perspective of a "gaze from below" - a reinterpretation of modern reality from the stand point of the former inhabitants of the Third World, who now have the opportunity to take part in the public life. The use of the phrase El Mundo Maya ("Mayan World") is taken as an act of proclamation of cultural pride. Modern Mayan identity, no matter if we speak of the Mayas in Guatemala itself or the Mayan diaspora in the US, combines various pieces of cultural references and puts in the center historical roots for contemporary actions. It may be regarded as "living in the past", but this kind of identity layers are considered by Mayas not as contradictory or artificial. They build a comprehensive structure of self, constructed from different elements into a hybrid whole.

The significance of language for forming modern Mayan identity may be regarded several ways. Language functions on a local level as an element contrib.uting to strengthening the inner ties of the community. It is caused by drawing the shape of the known social order through a common language. For many Mayas linguistic diversity delivers in this matter useful tools for the process of self-identification of the group. Local Mayan idioms are perceived as symbolic border lines of the culturally understandable world, social norms and values, or 
even ecological environment. On the other hand, being aware of the existence of a common Mayan linguistic family and of a broader cultural context builds the basis for the Mayan revitalization movement in Guatemala. Linguistic identity in this case is equal also with a global identity of indigenous groups living in similar conditions. This discourse on language role in creating modern Mayan culture and identity is of course today being put in a specific context of a political and social transition the country undergoes at the moment. Nevertheless it remains as a cultural discourse, despite obvious attempts to shift it more towards different groups of interest, political parties and ideologies which have nothing in common with the situation of the Maya.

\section{Literatura}

Baker C. (2006). Foundations of Bilingual Education and Bilingualism. Clevedon.

Fischer E.F., McKenna Brown R. (eds.). (1999). Maya Cultural Activism in Guatemala. Austin, Texas.

Fuentes C. (1997). A New Time for Mexico. Berkeley and Los Angeles.

Garzon S., McKenna-Brown R., Becker Richards J., Ajpub’ W. (1998). The Life of Our Language. Kaqchikel Maya Maintenance, Shift and Revitalization. Austin.

Hawkins J.P., Adams W.R. (2005). Roads to Change in Maya Guatemala. A Field School Approach to Understaning the K'iche. Norman.

Hendrickson C. (1995). Weaving Identities. Construction of Dress and Self in Highland Guatemala Town. Austin.

Metz B.E. (2006). Ch'orti'-Maya Survival in eastern Guatemala. Identity in Transition, Albuquerque.

Petrovic J.E. (ed.). (2010). International Perspectives on Bilingual Education. Policy, Practice and Controversy. Charlotte.

Tzian L. (1994). Mayas y ladinos en cifras. El caso Guatemala. Guatemala.

Wilson R. (1999). Maya Resurgence in Guatemala. Q'eqchi' Experiences. Norman.

World Bank (2005). Central American Education Strategy. An Agenda for Action. A World Bank Country Study. Washington.

\section{Wielokulturowość wymyślona na nowo. Edukacja dwujęzyczna w Gwatemali}

\section{Streszczenie}

Ameryka Łacińska jest regionem o skomplikowanej historii. Wpływa ona bezpośrednio na bieżącą sytuację społeczną w krajach takich jak Meksyk, Gwatemala i Honduras. Znaczącym elementem składowym tej sytuacji jest marginalizacja ludności tubylczej w krajach regionu. Proces marginalizacji Indian, zapoczątkowany przybyciem hiszpańskich osadników w XV wieku, pogłębiał się wraz 
z upływem czasu i doprowadził do wykształcenia struktur, w których stała się ona normą społeczną, ekonomiczną, polityczną oraz kulturową. Stan ten uległ zmianie dopiero wraz z końcem $\mathrm{XX}$ wieku, kiedy to zainicjowane zostały procesy, w efekcie których nastąpiła emancypacja grup tubylczych, takich jak na przykład ludność majańska. Współcześni Majowie, zamieszkujący głównie południe Meksyku i Gwatemalę, stanowią egzemplifikację grup tworzących trzon ruchów rewitalizacyjnych funkcjonujących w różnych zakątkach globu i dążących do przywrócenia kulturom tubylczym ich dawnej świetności oraz możliwości wyrażania ich własnej tożsamości kulturowej. Przyczynia się to do wypracowania w krajach takich jak Gwatemala nowej formuły wielokulturowości. Nowy model społeczny wypracowywany jest nie tyle na drodze społecznego konsensusu, co położenia znacznego nacisku na tubylczy aktywizm. Ujawnia się on na różnych płaszczyznach działań społecznych, $\mathrm{w}$ tym także na polu edukacji. Ważnym elementem tubylczego aktywizmu jest dążenie do wprowadzenia edukacji dwujęzycznej na obszarach o znaczącym odsetku grup tubylczych, jak również innych form pozwalających na zmniejszenie poziomu marginalizacji. Proces zmiany jest tu wielowymiarowy i dotyka różnych sfer życia publicznego. Niemniej to edukacja właśnie jest jednym z głównych obszarów działalności współczesnych Majów. Dostrzega to wielu majańskich aktywistów politycznych, jak np. laureatka Nagrody Nobla Rigoberta Menchu Tum. Podkreślają oni konieczność transformacji systemu edukacyjnego w Gwatemali, a wraz z nim zmianę całego systemu politycznego w taki sposób, aby grupy tubylcze znalazły uznanie i możliwość rozwoju. Zjawisko to jest znamienne dla przemian dotykających sporą część Ameryki Łacińskiej i nie jest wyłącznie charakterystyczne dla samej Gwatemali. Z drugiej jednak strony, przykład, jaki daje majański aktywizm, znajduje wielu naśladowców i wskazywany jest jako jeden z wzorów powolnego, aczkolwiek ukierunkowanego na sukces, włączenia grup dotąd wyłączonych z głównego nurtu kultur narodowych w tym obszarze. Edukacja dwujęzyczna jest jednak w Gwatemali nie tylko efektem tego rodzaju działań politycznych, lecz także koniecznością. Duże zróżnicowanie etnolingwistyczne tego kraju wymaga bowiem wypracowania platformy porozumienia tak pomiędzy ludnością majańską a tak zwanymi ladinos (metysami i białymi), co również pomiędzy poszczególnymi grupami językowymi samych Majów. 